\title{
THE EFFECT OF ANIMATED FILM ON STUDENTS' ABILITY TO WRITE NARRATIVE TEXT AT CLASS X MIA 5 OF SMAN 9 KENDARI
}

\author{
Sri Wahyuni \\ Halu Oleo University-Kendari, Indonesia \\ e-mail: erinwahyuni2@gmail.com
}

\begin{abstract}
The objective of this study is aimed to examine whether there is a significant effect of animated film on their ability in writing at SMAN 9 Kendari. The research question of this study was "Is there any significant effect of animated film on students" ability to write narrative text at class X Mia 5 of SMAN 9 Kendari?"

The population of this study was the entire of the first grade students of SMAN 9 Kendari who registers in academic year 2014/2015. This research involved 40 students at class X. The instrument of this study was writing task in narrative genre. And the criteria of students" writing were assessed from five aspects of writing, namely content, organization, vocabulary, language use, and mechanic. The data were obtained by using two essay writing tests. They were pre-test and post-test. The pre-test was given before the treatment and the post-test was given after the treatment finished.

The data of the pre-test and post-test were analyzed by means of descriptive and inferential statistics. After the data were tested and found to be normal, the hypothesis was tested using the analysis of paired sample test. The result showed that there was significant effect of students" writing ability after teaching by using audio visual media (animated film). It can be seen on the result of the hypothesis testing using paired sample test. The mean score of pre-test was 61.92 and mean score post-test was 75.63. Morever, as a result the probability value of .000 ( $p$ value) was less than the level of significant $(p<.05)$. Therefore, it can be said that using audio visual media (animated film) gives significant effect to increase students" ability to write narrative text at class X Mia 5 of SMAN 9
\end{abstract}

Kendari.

Keywords: Writing, Animated Film, Narrative Text

\section{Introduction}

Writing is called as a complex activity, in which, students as writers have to know how to generate and organize their ideas, and concern to some aspects of writing such as content, vocabulary, organization, language use (grammar) and mechanics, so that the readers can understand what they mean on their writing without any-existence of body language (gestures) just like occurred in speaking skill.

According Kitao \& Saeki (1992) also reveal that writing is considered as the most difficult of four skills to be mastered by both native and non-native language writers. They maintain that writing actually becomes an extremely complex activity which requires the writer to control a wide variety of complex information, ranging from letter formation and spelling rhetorical pattern. Writing actually is not an easy activity, but it is less difficult than many students imagine (Nida,2008). Winebrenner (1996) states if the teacher are flexible about the methods of teaching writing also needs enable students are able to write. The goal of teaching writing also needs enable students to communicate in ways which are flexible and meaningful for the students. Thus, methods that are carry out by techniques implementation in the classroom should be flexible and meaningful, in which students" writing also should anchor their world.

Writing becomes the main concern for teachers who teach English in Junior High School it is proved when the researcher interviewed the teacher at SMAN 9 Kendari. Researcher found that they almost do not understand all the content in their book, so when 
their teacher asked them to speak, read, listen or write, they do not know what they have to write and do because their writing is still lack.

Based on the facts above, the teacher needed variations in teaching writing. The teacher had find the media to make students interest to build their self confidence in writing. According Lynne (2001) the students" interest is one of the many factors to achieve the goal of teaching learning English. For that reason, animated film is a medium that can be used to increase students" motivation in learning writing cause students can hear the voice but they will see the situations that happen in the story and then they will be more interest and motivate using animation film in the class. Lavery (2008) argues that film and video are effective ways in motivating and helping students to understand language. So, with teaching using animated film, students will get interest and try to re-write the story from the film.

\section{Research Questions}

The research question of this study was: is there any significant effect of using animated film on students" ability to write narrative text at class X-Mia 5 of SMAN 9 Kendari?

\section{Hypothesis of the Study}

The hypothesis of the study was " there is a significant effect of using animated film on students" ability to write narrative text at class X-Mia 5 of SMAN 9 Kendari.

\section{Objectives of the Study}

The objective of the study is to find out whether or not there is a significant effect of using animated film on students ${ }^{\text {"e }}$ ability to write narrative text at SMAN 9 Kendari.

\section{The Significances of the Study}

The significance of this study are as follow:

- $\quad$ To show the advantages and disadvantages of using animated film (audio visual media) in teaching learning expecially writing text.

- As information for students in Senior High School about the effectiveness of using animated film in establishing writing

- To give information to the other researcher who are interested in carrying out the same research.

\section{The Scope of the Study}

The scope of the study was focused on students" to write narrative based on film at class $\mathrm{X}$ Mia 5 of SMAN 9 Kendari. The researcher was focuses on five aspect in writing especially content, organization, language use, vocabulary and mechanics.

\section{Definition of the Term}

To make sure the understanding of the readers when they were read this research, the writer gives some definitions of key of this study were as follow:

$\boldsymbol{\nearrow}$ Animated Film is process of giving the illusion of movement to drawings, models,or animate objects.

$\boldsymbol{\nearrow}$ Audio Visual media is one of media can be effective for teaching especially narrative writing because students can hear the voice but they will see the situation that happen in the story.

$\boldsymbol{\nearrow}$ Narrative is tells a story and entertains or informs the reader or listener (Anderson 1998:8) 


\section{Literature Review \\ Definition of Writing}

Sudaryanto (2001: 64) says that writing skill is a person's ability to express his/her mind and feeling which is expressed in a written language, in graphic symbols so that the readers are able to understand the message inside. In addition, Harmer (2004: 86) states that writing is a process that what we write is often heavily influenced by the constraints of genres, then these elements have to be present in learning activities. It means that writing cannot be separated with genres especially in teaching learning activities of writing. In this case, writing activities can be present in a classroom. So, Writing is an activity of thinking after which it is expressed into graphic symbols, in a communicative written language. In expressing the thought into a written language, feeling plays an important role as well, so that the products will be easily understood and enjoyed by the readers.

\section{Problems of Writing}

Writing has the most dificulties, since writing needs more accuracy for instance in spelling, grammar, and appropriate expression. Lacking of the accuracy will lead to missunderstanding. The readers might not be able to catch the message or the communication between the writer and the readers will not run well. According to Msanjila (2005), there are six common problems that may occur when doing writing. Those problems are capitalization problem, punctuation problem, inexplicitness or fuzziness, poor organization or illogical sequence, spelling problem, and the last is grammatical errors. It appears that out of the six writing problems, three are very crucial, including: the misuse of capital letters, inadequate use of punctuation marks and inexplicitness or fuzziness. Their impact is more serious than the other problems because the intended meaning is often misconceived. The students should pay attention on those six points to be able to make good writing assignments.

\section{Steps of Writing}

Acording Edelstein and Pival (1998 : 11) in Gustiawan, (2011 : 27-28) state that process of writing is described in the following sub-sections:

1. Pre-writing

Pre-writing refers to selecting the general subject, restricts the subject, generates the ideas and organizes the ideas. In this step, students involve the activities, such as reading, brainstorming, mind mapping, discussing, fast writing, questioning, interviewing, encourage them before they write their sentences in the first draft.

\section{Writing}

Writing denotes to setting on the paper the ideas in her or his mind into words, sentences, paragraph and so on. In this step, students start composing their ideas into piece of writing and concentrate on getting ideas down on paper without worrying about spelling or grammar, students just full attention to develop their ideas.

\section{Re-writing}

Re-writing concerns with evaluating her/his writing, deals mainly with correcting the content and form ,correcting the vocabulary, punctuation, and grammar, correcting writing errors, word duplications and omission. In this step, the students to re-examine or re-write their writing for some mistakes they have made based on the feedback given such as content, organization, language use, vocabulary and mechanic.

\section{The Assessment Technique of Students' Writing}

In assessing the students" writing Quality, Jacob (1981:60) suggests five components or criteria to evaluate the students" writing quality: content, organization, vocabulary, language use (grammar), and mechanics. 
Content of writing must be knowledgeable, substantive, through development of thesis, relevant to assigned topic. Organization of writing must be fluent expression, idea clearly stated/supported, succinct, well-organized, logical sequencing, cohesive. Vocabulary of writing must be sophisticated range, effective word/idiom choice and usage, word form mastery, and appropriate register. Language use (grammar) in writing activity, the students will create the sentences based on their ideas and the words in the sentences must be arranged grammatically which deals with tenses and agreement.

The last is Mechanics of writing which consist of spelling and punctuation (Capital letter, Period \{.\}, Question mark \{?\}, Exclamation mark $\{!\}$, Comma $\{$,$\} , Semi colon \{;\}$, Apostrophe $\{,\}$,

\section{Narrative Text}

Narrative is to tell a story or tale that orderly account of events in speech of writing Hornsby in Yatimah (2014). It is a piece of the text which tells story, entertains or informs the reader or listener. Pumamawati (2011), states that narrative text is an account of a sequence of events, usually in choronological order. Relating to kinds of text, which has students complete studying in high school narrative is a text which retells the story or previous the experiences. The purpose of a text is to amuse, entertain the reader or listener about the story. Narrative deals with problematic events which lead to a crisis or turning point of some kind, which in turn finds a resolution.

\section{Media}

According to Li-Ling KUO in Agusta (2015), media are the means for transferring or delivering messages. It is called the educational medium when the medium transfers message for the purpose of teaching. Meanwhile, Sugeng (2010: 154) says that a medium (plural form $=$ media) is a means by which something is expressed or communicated. A medium in the teaching learning process is a tool to match the learning objective and the learning product. It means to select media the teacher should consider the learning objective and the learning product.

\section{The Use of Audio Visual Media (animated film) in the Classroom}

There are three media in teaching. They are audio, visual, and audio-visual. Audiovisual media more effective to used in the class because audio-visual media, the students not only hear but they also can see. The sample of audio-visual media that are usually used are: television, video, film etc. Students can learn faster and easier by audio visual processes than by verbal explanation only.

According to Harmer (2001) the use of audio visual media in writing can motivate students because they will get information on what they should write or tell in relation to the video then they will get an interest to develop their ideas. Furthermore, Harmer (2001) claims that a film or video is one of the visual aids that can be used in a writing class.

\section{Animated Film}

Maltin (1980) defines that animation is a graphic representation of drawings to show movement within those drawings. A series of drawings are link together and usually photograph by a camera. Examples of animation are Micky Mouse, Donald duck, Doraemon, etc.

\section{Animated Film in Teaching Narrative Text}

Moss (2010) states that the animation film in writing process can organize brainstorming session well. For that reason, animated film help students to improve their 
ability in English especially writing cause students will learn some elements of narrative text such as characters, dialogues, plots, conflict and climax.

By using animated film, it will make students understand the generic structure of narrative text, shows real images, plot or simple story and they provide contextual clues to the meaning of written narrative.

Vukoja ( 2005) states that through the use of animation video or film in prewriting activity, students can explore the structural device of the story (plotlines, character development, setting, and theme). So, the students will be easier to learn about narrative text and they will try to write their story.

\section{Methodology of the Study Design of the Study}

The design of this research was Pre-Experimental Design (one group pretest and posttest design) by using one class that is gave pre-test and post-test. Ary et al (1997) states that this design provides no class control. That presentation followed the scheme below:

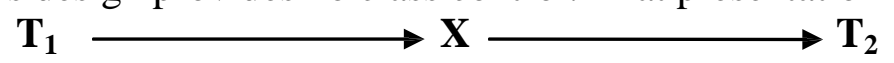

Where:

$\mathrm{T}_{1} \quad=$ Pre-test

$\mathrm{X}=$ Treatment $\mathrm{T}_{2}$

$=$ Post-test Population

and Sample

Population of the study was all of the students at class $\mathrm{x}$ of SMAN 9 Kendari who are registered in academic year 2014/2015. The total of population are 327 students. Therefore, technique of taking sample of this research was purposive sampling.

\section{Instrument of the Research}

The instrument of the research was written test. The researcher administered writing test to find out whether the students ability to write narrative writing can improved or not through animated film. The writing test that used the test to measured the students" ability after being taught animated film at the first grade students of SMAN 9 Kendari and the students write a simple narrative text about 100-150 words or two paragraph or more about less from 90 minutes.

\section{Technique of Data Analysis}

In this research analyzed use descriptive and inferential statistic. Descriptive statistic was described the maximum and minimum scores, mean, and deviation standard. While the inferential statistic used to examine the hypothesis in SPSS 16.0 for windows (one tailed test).

\section{Marking Scheme}

For evaluating students" writing compositions, the researcher used five aspects of writing band score from ESL composition profile proposed by Jacob et al (1981:67).

\section{Inter Rater Agreement}

for measuring the students" score, the writer used two independent raters. In this research, the raters were the reseacher herself and the teacher who teaches in that class. The data can bee seen as follow: 
Appendix 13 . Data of Inter Rater Agreement Analysis from the Two Raters.

\begin{tabular}{|c|c|c|c|c|c|}
\hline \multirow{2}{*}{ Resp. } & \multicolumn{2}{|c|}{ Students' Score } & \multirow{2}{*}{$\mathbf{X}^{\mathbf{2}}$} & $\mathbf{Y}^{\mathbf{2}}$ & XY \\
\cline { 2 - 3 } & Rater 1(X) & Rater 2(Y) & & & \\
\hline 2 & 62 & 64 & 3844 & 4096 & 3968 \\
\hline 5 & 58 & 60 & 3364 & 3600 & 3480 \\
\hline 9 & 78 & 76 & 6084 & 5776 & 5928 \\
\hline 22 & 69 & 67 & 4761 & 4489 & 4623 \\
\hline 36 & 55 & 56 & 3025 & 3136 & 3080 \\
\hline & $\mathbf{\Sigma X 3 2 2}$ & $\mathbf{\Sigma Y 3 2 3}$ & $\mathbf{\Sigma X}^{2} \mathbf{2 1 0 7 8}$ & $\mathbf{\Sigma Y}^{\mathbf{2} 21097}$ & $\mathbf{\Sigma Y 2 1 0 9 7}$ \\
\hline
\end{tabular}

The formula of product moment:

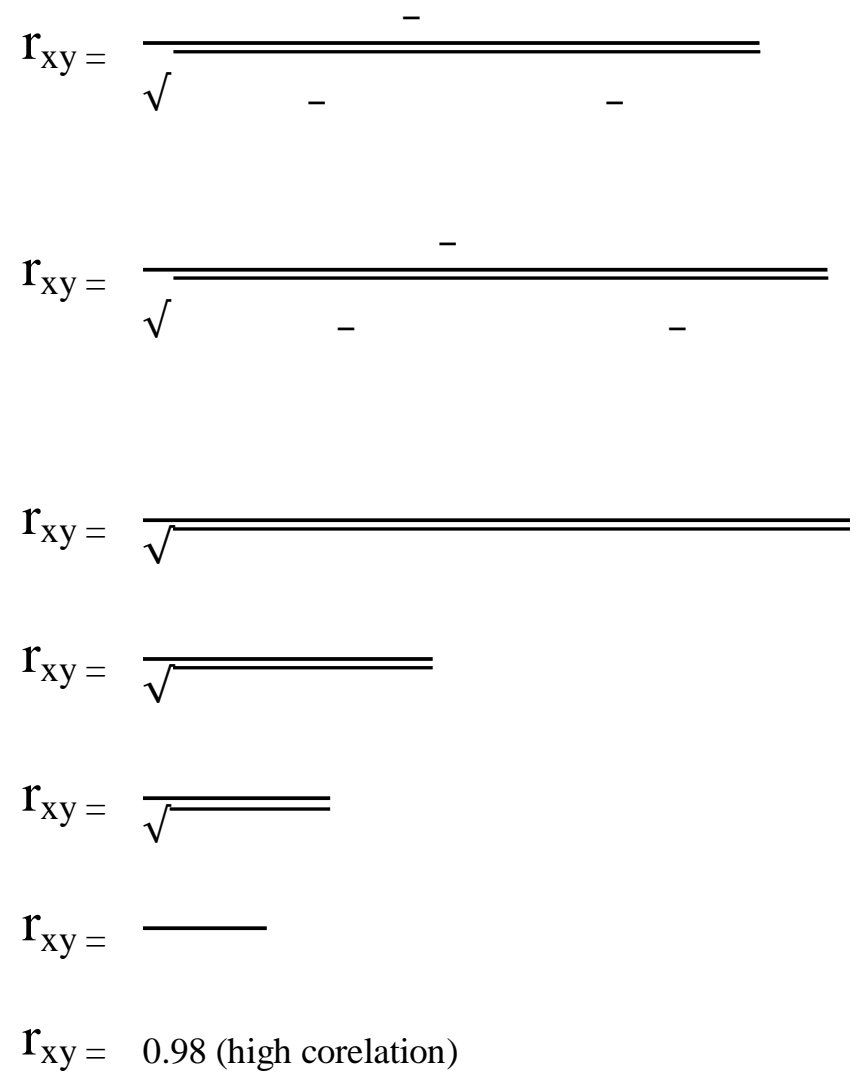

4. Finding and Discussion

Descriptive Statistical Analysis

Table 4.5 Descriptive Analysis of Students' Pre-Test and Post-Test Score

\begin{tabular}{|c|c|c|c|}
\hline $\begin{array}{c}\text { Descriptive } \\
\text { Analysis }\end{array}$ & Pre-Test & Post-Test & Gain Score \\
\hline Mean Score & 61.92 & 75.63 & 13.71 \\
\hline SD & 4.981 & 3.488 & 1.493 \\
\hline Max. Score & 77.00 & 83.50 & 6.50 \\
\hline Min. Score & 54.50 & 68.50 & 14 \\
\hline
\end{tabular}

Both pre-test and post-test are done to measure the students" writing composition before and after teaching and learning process through treatment. The tests are used to check 
and find out whether the technique works or not. The table 4.5 shows that there was significant score before and after used animated film technique in writing narrative text.

Based on the table above, the mean score on pre-test is 61.92 while in post-test becomes 75.63 . Then, the maximum score on pre-test is 77.00 while in post-test is 83.50 with gain score is 6.50 and the minimum score on pre-test 54.50 while in post-test becomes 68.50 with gain score is 14 . In brief, it is clear that there is an improvement on students" writing ability after being given treatment.

Besides, the researcher showed the table below to know the differences pre and post test includes their minimum and maximum score, mean, standard deviation, etc.

Table 4.6 Descriptive Statistics Between Pre and Post-Test

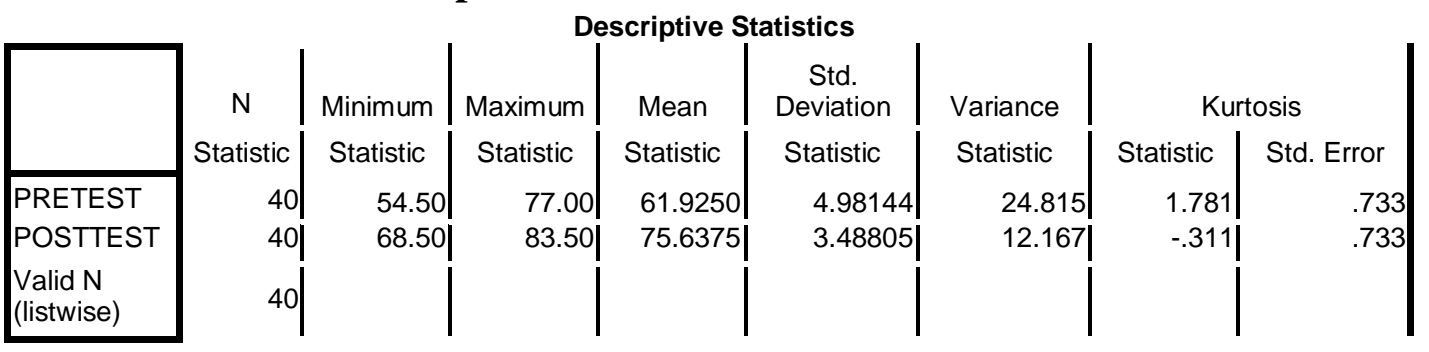

In addition, by comparing students" post-test scores based on the data from the table 4.6, the researcher concludes that there was a significant difference of students" writing ability that is taught by using animated film. It can be seen from the descriptive statistics analysis of students score in post-test. The mean score in pre-test is 61.92 while in post-test is 75.63 , so the gain scores 13.71 . The maximum score in pre-test is 77.00 , while in post-test is 83.50; and the minimum score in pre-test is 54.50, while in post-test is 68.50 , so the gain score of maximum is 6.50 points and minimum score is 14 points. It means that there was a different level of students in pre-test and post-test after being given treatment. Therefore, the researcher concludes that animated film technique given significant effect on the students" ability to write narrative text. On the other words, it was effective to improve the students" ability to write narrative text.

Also, based on all the findings after being given treatment, it shows that there was no student who obtained in "very poor" writing ability. There were only one students who obtained in "fair to poor" writing and the most of the students who obtained "good to average" and one students who obtained "Excellent to very good". Besides that, the mean score (M) of the students writing is 75.63 , the students" writing ability was categorized in "good to average" writing ability. It means that animated film improved the students writing ability.

Graph 4.1 The Comparison of Students' Mean Score of Pre-Test and Post-Test

\section{Mean Statistic}

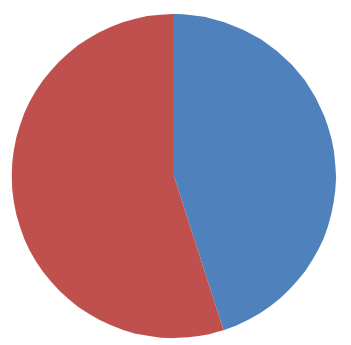

- Pretest

- Posttest

The graphs shows students" mean score in post-test is raise 13.71 point from 61.92 for pre-test to 75.63 for post-test. This result proves that the students "writing ability who taught by using animated film gives significant effect on students" writing ability. 


\subsubsection{Means Score of Five Aspects Score of Writing Composition on Pre - Test and Post Test}

Table 4.6 Means Score of Five Aspects Score of Writing Composition on Pre - Test and Post Test

\begin{tabular}{|c|c|c|c|c|c|}
\hline \multirow{2}{*}{ No. } & \multirow{2}{*}{ Component } & \multicolumn{4}{|c|}{ Mean Score } \\
\cline { 3 - 6 } & & \multicolumn{2}{|c|}{ Pre - Test } & \multicolumn{2}{c|}{ Post Test } \\
\cline { 3 - 6 } & & Raw & Score & Raw & Score \\
\hline 1 & Content & 18.46 & 6.15 & 20.15 & 6.71 \\
\hline 2 & Organization & 14.52 & 7.26 & 17.21 & 8.60 \\
\hline 3 & Vocabulary & 13.13 & 6.56 & 17.38 & 8.69 \\
\hline 4 & Language Use & 13.23 & 5.29 & 17.43 & 6.97 \\
\hline 5 & Mechanics & 2.57 & 5.14 & 2.58 & 5.16 \\
\hline
\end{tabular}

The data above indicates that in content, the means score of pre-test was 6.15 and posttest was 6.71 . The difference of both scores is 0.56 . In organization, the means score of pretest was 7.26 and post-test was 8.60. This shows that the difference of both scores is 1.34 . In vocabulary, the means score of pre-test was 6.56 and post-test was 8.69. The difference of both scores is 2.13. In contrast, in language use, the means score of pre-test was 5.29 and post-test was 6.97. This shows that the difference of both scores is 1.68. In mechanics, the means score of pre-test was 5.14 and in post-test was 5.16. The difference of both scores is 0.02 .

To make clear the interpretation of those scores above, the researcher used column chart to see the students" performance in each aspect of writing composition after using audio visual (animated film) technique.

Graph 4.2 The Means Score of Five Aspects of Students' Writing Composition

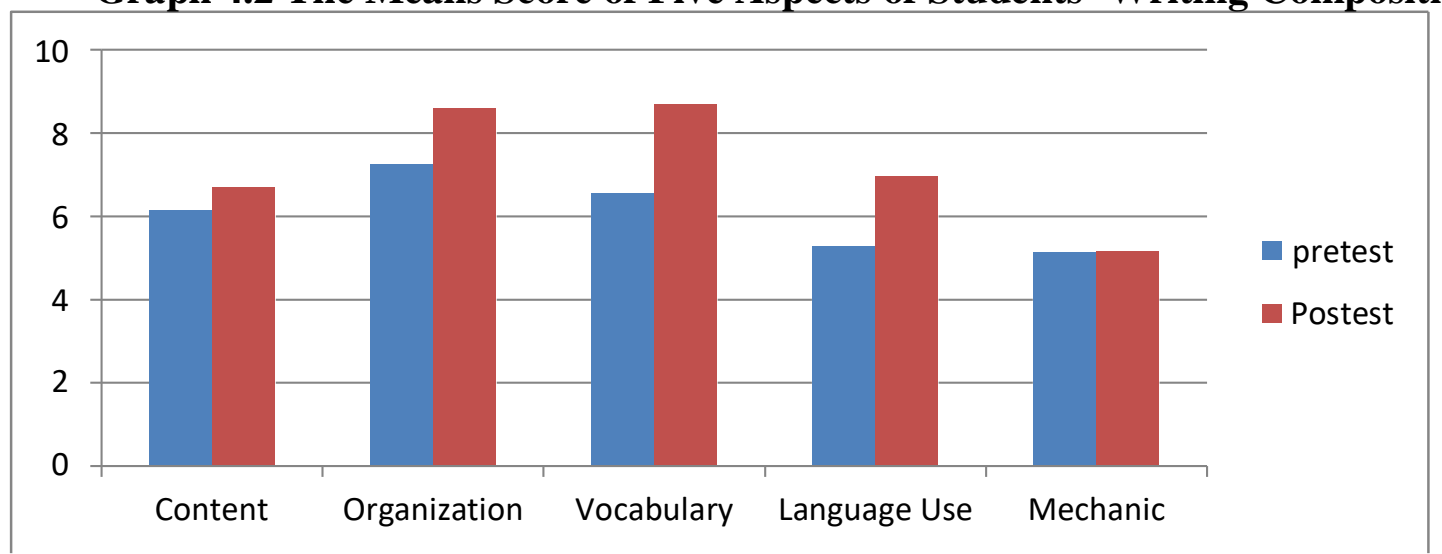

The chart above compared the result of pre-test and post-test of five aspects of writing composition, particularly content, organization, vocabulary, language use, and mechanics. In addition, from those differences means scores, five aspects of students "writing compositions increased. In content, it was 18.46 in pre-test and 20.15 in post-test. In organization aspect, it was 14.52 in pre-test and 17.21 in post-test. In vocabulary aspect, it was 13.13 in pre-test and 17.38 in post-test. Meanwhile, in language use, it was 13.23 in pretest and 17.43 in post-test. In mechanic aspect, it was 2.57 in pre-test and 2.58 in post-test.

\section{Normality Test}

Normality test is intended to show that the data samples come from populations that are normally distributed. Data were tested for normally using based on the KolmogorovSmirnov test. Kolmogorov-Smirnov normality test is widely used. especially after many outstanding statistical programs. Theoretically, if the $\mathrm{p}$ value is greater than 0.05 ( $\mathrm{p}>0.05)$, it 
means that the data are normally distributed. In contrast, if it is less than $0.05(\mathrm{p}<0.05)$, it means that the data significantly deviate from a normal distribution. The result of the normality test of students" pre-test and post-test score can be seen as follow:

Table 4.8 The Result of the Normality Test of the Students" Score

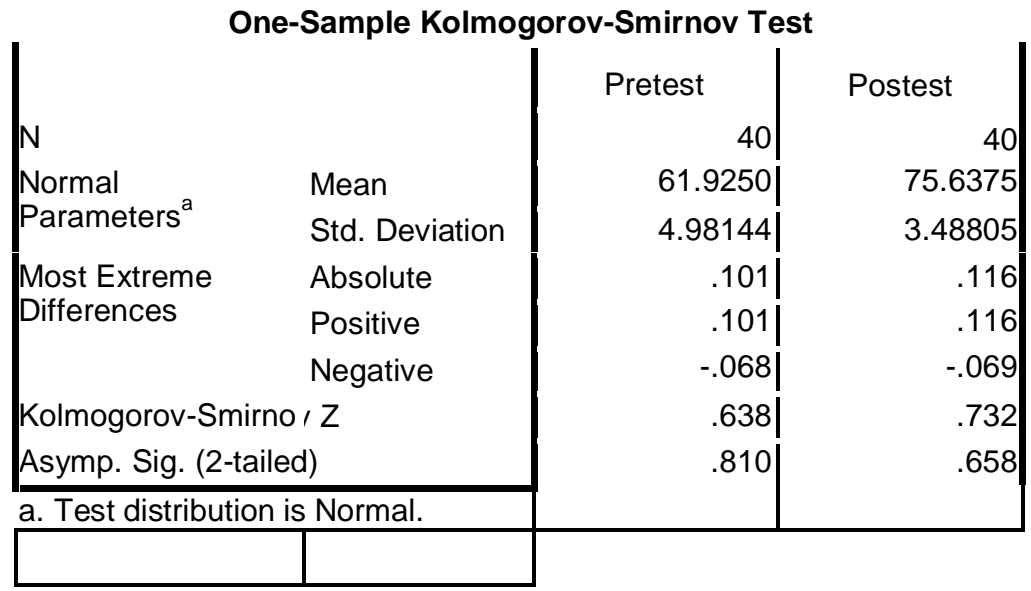

To determine the data is normally distributed, Probability value ( $p_{\text {value }}$ ) of the data must be higher than alpha $(\alpha=0.05)$. The table 4.8 displays the normality of pre-test and post-test score. The result of normality for the pre-test is 0.810 ( $\left.p_{\text {value }}>.05\right)$. Meanwhile, the result of normality for the post-test is 0.658 ( $\left.p_{\text {value }}>.05\right)$. Finally, it can be conclude that all of the data both pre-test and post-test are normally distributed.

\section{Effect Size}

The effect size was calculated to investigate how significant the effect of independent variable in practical terms is. If the treatment works well then there will be a large effect size. The effect size in this research is 0.95 because it is bigger than the minimum threshold of 0.80 (cohen 1988).

\section{Discussion}

The implementation of animated film in teaching learning narrative text was started when the researcher explained to the students about the purpose, the generic structure and the language features of narrative text. The researcher then introduced animated film to the students and presented the way, how to write narrative text based on the animated film. The researcher gave several questions which are related to the film. The next step was playing the animated film and the students tried to answer the questions on the worksheet provided. In this step, the teacher gave times chance to the students to answer the questions provided. In this activity, the researcher helped students to encourage and explore the student ideas in writing a narrative text. The answer from the questions helped the students to elaborate their ideas. Finally, the teacher asks the students to write a narrative text based on animated film is played.

When apply the animated film technique, the researcher prepared three topics and automatically prepared three films too. For the first topic, the researcher acted a teacher provided "The Man and The Tiger" animated film. This film in does not have subtitle. Some of questions had prepared by teacher to help students more easy to gotten idea in writing narrative text.

All case during film played proposed to students to achieve their writing ability especially in five aspects of ESL Components likes content, organization, vocabulary, language use and mechanics because based on theory of according Jacob (1981:90) states that the characteristic of good writing if its content was knowledgeable, through development of thesis and relevant to assigned topic. Its organization must be flient expression, well organized, ideas clearly, stated and supported and logical sequencing. Its vocabulary must be 
supplicated range, effective word/idiom choice and usage and appropriate register. Its language use must be few errors of agreement, tense, number , word order, pronouns, capitalization and paragraphing.

For the second topic when apply in meeting two, the researcher used topic "Sleeping Beauty" that does not subtitle. Where the story writer read a story "sleeping beauty" without presents the story didn "et written. So the students have to use their listening achievement and visual achievement to know and understanding the story.

This film provided by teacher where little difficult from the film on the meetings before because the teacher want made students exercise their thinking and their ability to write. So, do with the third meeting, the teacher used topic "How Tiger Got His Stripes" without subtitle too and more difficult to understand without the topic on second meetings to same proposed. After did all treatments, the teacher hold post-test to compared with pre-test that had hold before treatment. The students written same topic for pre and post such as " Cinderella" to made teacher more easy to calculate the students achieved before and after taught by animated film.

The result was the researcher concludes that there was a significant difference of students" writing ability that is taught by using animated film technique. It can be seen from the descriptive statistics analysis of students score in post-test. The mean score in pre-test is 61.92 while in post-test is 75.63 , so the gain scores 13.71 .

The maximum score in pre-test is 77.00 , while in post-test is 83.50 ; and the minimum score in pre-test is 54.50, while in post-test is 68.50, so the gain score of maximum is 6.50 points and minimum score is 14 points. It means that there was a different level of students in pre-test and post-test after being given treatment. Therefore, the researcher concludes that animated film technique given significant effect on students" ability to write narrative text.

Also, based on all the findings after being given treatment, it shows that there was no student who obtained in "very poor" writing ability. There are only one students who obtained in "fair to poor" writing and the most of the students who obtained "good to average" and one students who obtained "Excellent to very good". Besides that, the mean score (M) of the students writing is 75.63 , the students" writing ability was categorized in "good to average" writing ability. It means that animated film improved the students writing ability

Based on the result of this study, the probability value $\left(p_{\text {value }}\right)$ was less than the level of significance $(p>.05)$. As a result, it can be concluded that $\mathrm{H}_{0}$ is rejected and $\mathrm{H}_{1}$ is accepted. It can be said that animated film method gives a significant effect on students" writing ability at class X Mia 5 of SMAN 9 Kendari.

Furthermore, the result of paired sample t-test shows that the value of significance was less than $0.05(p(.000)<0.05)$. It means that there was a significant difference on students" writing ability before they were taught with using animated film. Consequently, the hypothesis proposed in this research which says "there is significance effect of using animated film on students" ability to write narrative text at the class X MIA 5 of SMAN 9 Kendari "was accepted.

This significant effect on the students" writing ability with using animated film in this study was not directly happen without some things affecting, but rather affected by supporting factors. The use of animated film in this study was one of the major effects to the improvement beside other factors, such as motivation, material, and made the students worksheet more easy with help students to imaginative to got their ideas with the teacher showed the animation film and the teacher provided questions to students so after the students watch and answer the questions, the students more easy to made and develop a title to write a paragraph of narrative text. 


\section{Conclusion and Recommendation Conclusion}

This research is aimed to find out the effectiveness of implementation audio visual media in teaching writing narrative text. This is also to answer the research question that mentioned earlier, that is to find out whether their is significant effect of using audio visual media on students" ability to writing.

Reffering to the findings and discussion that have been elaborated in the previous chapter, it showed that showed that after getting several treatments, there were significant differences means scores between students are taught using audio visual media (animated film) in teaching activities. It indicates that the audio visual media is more effective to improving students" ability to write narrative text of the first grade of SMAN 9 Kendari. it supported by the data nd evidence from the result of statistical calculation SPSS 16.0 for windows. In other words, the implications of the findings suggest that audio visual media tehnique gives positive effects on students" ability to write narrative text.

\section{Recommendation}

After conducting this research, the researcher offers several recommendations for further researcher. They are in the following:

1. The result of this study showed that most students still found difficult in term of content, organization, language use, vocabulary, and mechanic. Therefore, it is imperative for the teacher to encourage the learner in giving more emphasizing to these five items in composing genre. Morever, the teacher should more vary the animated film using audio visual media in teaching learning process before they write by them selves.

2. This research focuses in five aspects of writing taught through animated film (audio visual). For the next researcher: it is possible to carry out the research concering the use of animated film ( Audio-Visual Media) technique in teaching another English skills by using the same or different design.

\section{References}

Anderson, G. 1998. Fundamentals of Educational Research. London: Falmer Press.

Ary, D., Jacobs, S.L., and Dazavich, A. 1979. Introduction to Research in Education. USA: Holt, Rinchart and Winston.

Cohen, J. 1998. Statistical Power Analysis For the Behavior Science $\left(2^{\text {nd }}\right.$ ed). New Jersey. Lawrence Elbaum.

Edestein, Michael. E and Pival, Jean. G. 1998. The Writing Commitment. Newyork: Harcourt Broce Javanovich Publisher.

Gustiawan, Riska. 2011. Improving Students' Narrative Text Writing Through Contextual Teaching and Learning (CTL) at the Second Year of Senior High School 9 Bandar Lampung.

Harmer. 2001. The Practice of English Language Teaching $3^{\text {rd }}$ Ed, Longman: Pearson Education. 
Jacobs, H.L. Stephen, Deanna, V. Faye, Jane. 1981. Testing ESL Composition: A Practical Approach. Rowley, London, Tokyo. Newbury House Publisher

Kitao, S \& Saeki, N. 1992. Process and Social Aspect of Writing. Theory and Classroom Application Annual Reports of Studies. 33 (1), 86-102. Retrived from Http://www.eric.ed.gov/pdfs/Ed369288pdf.

Li-Ling Kuo and Christine. 1981. The Importance of Educational Media in Teaching in Bulletin of Social Education. Vol 20 pp 61-88

Lavery, Clare. 2008. Activities For Using Comics Strips. From www. Teachingenglish.org accessed on July 14, at 15.30 am

Lynne, Cameron. 2001. Teaching Language to Young Learners. Cambrigade University Press.

Maltin, Leonard. 1980. Of Mice and Magic: A History of American Animated Cartoons. Newyork: Plume.

Moss, Lauralee. 2010. Types of Audio-Visual Material Used in Teaching. Retrived on July 2014.

Msanjila, Y.P. 2005. Problems of Writing in Kiswalihi: A Case Study of Kiguruyembe and Morogoro Secondary Scholls in Tanzania. Nordic Journal of Afrian Studies, Vol 14 (1), 15-25.

Pumawati, Nuning. 2011. Understanding Text Type I, Semarang

Sugeng, Bambang \& Noor Zaimah. 2010. Contextual English 2: For Grade XI of SMA Physical Sciences \& Social Sciences Major. Solo: Pt Tiga Serangkai Pustaka Mandiri.

Sudaryanto. 2001. Peningkatan Keterampilan Menyusun Wacana Narasi Melalui Penerapan Pendekatan Ekletik. Cakrawala Pendidikan. Th XX, No 1. 61-69.

Vokuja, Tanya. 2005. Cross Genre About to Short Stories. Retrieved on July 2014.

Winebrenner, S. 1996. Teaching Gifted Kids in the Regular Classroom. Minnea Polis, Mn: Free Spirit.

Yatimah, Durotul. 2014. The Effectiveness of Using Animation Film as the Medium in Writing Narrative Text (An Experimental Study in the Second Grade Students at SMPN 3 Salatiga in the Academic Year 2013/2014). Stain 